\title{
Disrupting dual monolingualisms? \\ Language ideological ordering in an internationalising Swedish university
}

This chapter investigates the ways in which various discursive processes within and about Swedish Higher Education (HE) are rendering some value-laden linguistic practices and processes invisible. Previous studies in the field of Language Policy and Planning (LPP) have focused on the 'internationalisation' of HE with a pre-occupation for opposing linguistic systems, for example, Swedish and English. However, this study reveals how such dualistic thinking can (re)produce essentialising and highly ideologized monolingual and monocultural categories, over-simplifying what is understood by the 'international' and 'national' in contemporary HE. Drawing on data from an interview-based study carried out in a sciences department at a major Swedish university, this chapter demonstrates the potential in taking a multilingual approach when seeking to better understand the affordances and constraints of internationalisation.

\footnotetext{
Author Bio

Luke Holmes is a PhD candidate at the Centre for Research on Bilingualism at Stockholm University, Sweden. His main research interests are sociolinguistic and ethnographic in nature, focusing on increasingly diverse and trans-local academic contexts, and ideological processes unfolding therein. He has a background in English language and literacy teaching, with teaching experience from the UK, Spain and China.
} 


\section{Disrupting dual monolingualisms? \\ Language ideological ordering in an internationalising Swedish university}

\section{Introduction}

Since the Bologna process in the late 1990s, which formalised the international status of many universities across Europe, and in response to increasing diversity in staff and student profiles, Higher Education Institutions (HEIs) have been motivated to take up processes and policies that have been termed "internationalisation". To get an initial sense of the ways in which the diversity of Western HEIs has intensified, one need only consider the ways in which those involved in higher education now compete on the academic market. Doctoral students and academic staff — the focus of this study — now compete for positions and funding across national borders; nation states compete with other nation states by means of the symbolic and epistemic capital accumulated by their respective HEIs; and the HEIs themselves compete in various rankings to be recognised as international with a view to making symbolic, epistemic and economic gains. In this chapter, I will look to what is happening "on the ground" and the perspectives of those living through internationalisation. More specifically, this chapter provides an examination of reported everyday experiences of contemporary university life given by three international researchers, who, with varying volumes of academic power, are working at a major Swedish university. This will be done with a view to revealing how persons, practices and resources are constructed by the language policies, ideologies and practices of internationalisation in Sweden.

I will begin this chapter by providing a broad outline of the recent changes seen in Swedish HE in relation to the policies and processes of internationalisation together with the ways it has been discussed in the field of Swedish Language Policy and Planning. I will then situate my own research within the interpretative paradigm of multilingualism as part of the 
broader fields of critical sociolinguistics and linguistic anthropology, also providing a summary of my conceptual toolbox: "iconicity", "erasure" and "fractal recursivity" (Irvine and Gal 2000) as ideological processes that help to illustrate and better understand the “orders of visibility" (Kerfoot and Hyltenstam 2017) present in any given context. After outlining my methodology, I will go on to analyse and discuss my data, before making some concluding remarks, proposing how and why multilingual approaches to researching internationalisation can contribute to a more vital understanding of the struggles taking place in modern university life.

2. Modern higher education institutions as both 'national' and 'international'

Despite, or perhaps because of, the increasingly diverse and transnational flows encouraged by internationalisation, the contemporary academic market in northern Europe (at least) is one in which the use of English has come to prevail in certain key areas. This fact is well documented and represented in language related research. English is shown to dominate in academic publishing (Lillis and Curry 2010) - an element of knowledge production, in the sciences at least, with which "internationalism" is most typically associated (Paasi 2005). In Sweden, nearly 9 out of 10 doctoral theses, across all disciplines, are written in English across all disciplines (Salö 2010). Also, in the classrooms, English-medium instruction (EMI) has been increasing, especially in the Netherlands and the Nordic countries (cf. Airey et al. 2017). In 2007, in a survey that addressed 2,218 European HEIs, from the 851 HEIs that responded, there were already more than 400 HEIs offering a total of more than 2,400 (underand post-graduate) programmes taught entirely in English (Wächter and Maiworm 2008). By 2014, in a survey that addressed 2,637 HEIs, from the 1,155 HEIs that responded, more than 8,000 (under- and post-graduate) programmes taught in English were identified, 822 of which 
were identified in Sweden, with only the Netherlands $(1,078)$ and Germany $(1,030)$ offering more (Wächter and Maiworm 2014).

The drive for internationalisation is represented as being something akin to "Englishisation" (Kirkpatrick 2014), especially since, in line with the policies and practices of internationalisation, English medium academic practices are now recognised as a prerequisite of research quality and "impact", most visible in the symbolic value placed on publications in journals and books with the greatest reach (i.e. written in English). Most high profile academic publishing is in English and the teaching done through the medium of English offers various stakeholders significant gains in terms of symbolic and economic capital, not least as a result of the corresponding ranking criteria in two major university rankings, published by the Shanghai Jiao Tong University Institute of Higher Education and in the Times Higher Educational Supplement (Kauppi and Erkkilä 2011). Thus, the policies and practices of internationalisation, with their implicit and explicit demand for the increased use of English, are in the interests of those stakeholders concerned with gains in the academic marketplace. This is not to mention those individuals and institutions who see high English proficiency as a way towards economic prosperity (Song 2015). One response to such forces typically associated with internationalisation might be to ask how international HEIs really are. What of the diversity in the linguistic resources that are brought into university spaces by all of those international staff and students who now dwell there? Such a response is seldom found in the debate, as is the case in Sweden and other Nordic countries. Salient in its absence (or at least, lack of specificity), the multilingualism within Swedish HEIs is not seen to be in focus for either the Swedish government, Swedish HEIs, or researchers in the Swedish field of Language Policy and Planning.

The Nordic Council of Ministers (2007) responded to the above described "Englishisation" by recommending that English should be regulated at the governmental 
level. These recommendations led to The Swedish Language Act (SFS 2009:600), which establishes Swedish as the principal language of Sweden, but makes no mention of English. In fact, it gives special status to five minority languages and stipulates that speakers of other languages have the right to speak and learn their own languages. The Language Act, then, can be said to address concerns for multilingualism in society. However, in preparation for the language Act, Higher Education was marked out as a special case (Prop. 2004/05:162; Prop. 2005/06:2; Prop 2008/09:153, in Karlsson \& Karlsson 2019) in such a way that provides Swedish with certain protections and English with enough space to allow for Swedish HE to be globally competitive (cf. Karlsson \& Karlsson 2019: 5-7).

The debate surrounding the threat of English and the extent of its seriousness has been a strong theme in the field of Swedish Language Policy and Planning over the past few decades (cf. Melander \& Thelander 2006, Milani \& Johnson 2008, Salö 2016). Perhaps the more extreme stance is that which is concerned with the "national" and the survival of Swedish in HE. For instance, Teleman (1993, cited in Berg, Hult, King 2001), writing in, for and about Sweden, suggests that internationalisation in HE has led to a diglossic situation in certain academic areas, such as in the sciences, in which English is considered to have a higher status than Swedish. Such concerns are also seen in the work of Gunnarsson \& Öhman (1997) and Gunnarsson (2001), who reiterate the perceived threat of English to Swedish in terms of diglossia and "domain loss". Echoing the concern of policy makers (Committee for the Swedish Language 2002), it is argued that since more teaching is done through the medium of English, and more and more research is written and published in English, Swedish may continue to lose "domain" in Swedish HE and perhaps later become redundant there. Researchers will, it is said, lose their ability to use specialist Swedish terminology to talk about their work and thus will come to rely entirely on English for their academic purposes. 
Consistent with governmental, regional and selected scholarly recommendations, then, some Swedish HEIs have worked to re-empower Swedish by offering "parallel language policies" (cf. Hult \& Källkvist 2016; Kuteeva and Airey 2014). Such policies seek to guarantee a place for Swedish, alongside English, at the top of the linguistic hierarchy within Swedish HEIs, safeguarding it against the risk of losing its usefulness as a scientific language and as a medium of instruction. At the level of the local HEI, however, the Swedish Higher Education Authority (2008: 37) made no specific requirements and gave all Swedish universities free reign to develop their own language policies according to local circumstances, goals and priorities (cf. Karlsson \& Karlsson 2019). While this policy appears to leave the door open for those who seek to show a way forward in response to what is happening on the ground, research suggests that for local policy makers there may still only exist an ideological duel between two often named languages: English and Swedish, as the international and national languages respectively (Hult 2012, Källkvist \& Hult 2016; Hult \& Källkvist 2016).

An ideological duel between English and Swedish, then, draws on and is aligned with the national and local policy and scholarly debates outlined above, none of which reveal anything of the linguistic and social complexities that internationalisation has brought into Swedish university life. As such, in this study, while seeking to build from existing research, I strive to maintain my distance from such a duel and remain sensitive to the ways in which internationalisation, as my research object, has been constructed and the ways in which my participants experience and respond to this.

3. Static and flexible multilingualism

The prevalence of two languages in Swedish HE, as opposed to one, both largely beneficial to the nation state (Hult 2012), might prima facie tempt one to identify Swedish 
HE to be a multilingual, or at least bilingual field. After all, teachers, researchers and administrators will often be required to work and communicate in more than one named language, e.g. according to HEIs' policies of parallel language use. However, such policy relates to only two named languages. In this sense, these policies of internationalisation can be said to be ideologically monolingual, comprising of two monolingualisms - two named languages, understood as distinct and fixed linguistic systems (cf. Gramling 2016). As Wee $(2015,2017)$ describes it, there is a certain fixed-ness to the institutional linguistic practices found in universities. Universities' continued legitimacy in some senses depends on their conforming to various regulatory requirements, such as, for example local parallel language policies. Their legitimacy also depends on their acting in accordance with language ideologies from political and scholarly debates, such as the need to use English and Swedish for certain purposes, i.e. compete on the global market and (re)legitimise Swedish as the rightful language of the nation. Through this on-going process of legitimisation, these languages' positions at the top of the language hierarchy appear fixed. This is not multilingualism as it is most commonly understood in contemporary sociolinguistics, nor is it what Otusji and Pennycook (2011: 45) call "plural monolingualism", but rather a case of dual monolingualism, since there are only two visible languages.

A fixed approach to multilingualism, then, is one that focuses on the use of two or more named and separate linguistic systems. This can be contrasted with a more flexible approach that looks instead towards the complex of resources, such as concrete accents, varieties, registers, genres and modalities (Blommaert 2010: 102), and the ways in which they are used in particular communicative settings and spheres of life. This study takes such an approach and, following Heller (2007), seeks to contribute to and open up the debate by providing an understanding of how people with their resources and in their working practices are included and excluded as a result of this constructed Swedish-English dichotomy. 


\section{Constructing orders of visibility}

Where some linguistic practices and resources, for example carrying out and publishing research in English, are constructed as legitimate and made visible, others will be less so, thus revealing different "orders of visibility" (Kerfoot \& Hyltenstam 2017). As defined by Kerfoot and Tatah (2017: 38), the concept "orders of visibility", "draws attention to the shared frames of reference and meaning-making practices that construct, legitimate, and obscure relations of power", and it is through these meaning-making processes, the authors describe, that certain sociolinguistic features are made salient and inserted into hierarchies of power. As described above, this study seeks to remain sensitive to the ways in which the ideologies reproduced in the language policy, language debates and scholarship surrounding the internationalisation of Swedish HE may serve as shared frames of reference. In order to draw out the processes of construction of (in)visibility, however, I will seek to make use of the tool box provided by Irvine and Gal (2000), which helps us to better understand the processes by which ideologies "recognise" difference among practices, "how they locate, interpret and rationalise sociolinguistic complexity, identifying linguistic varieties with 'typical' persons and activities and accounting for the differentiations among them" (Gal and Irvine, 1995:972).

The first ideological process is iconicity. This process is one that transforms and fixes the relationship between linguistic features or varieties and the social images to which they are linked. Such a process has an essentialising character, in that a linguistic practice or feature becomes indexical of a social group's essence. For example, a speakers use of Mandarin Chinese can be described in such a way that discursively constructs that speaker as necessarily Chinese and, perhaps, in line with certain stereotypes, having some sort of imagined Chinese nature (see section 6.3). 
The second process, fractal recursivity is a process in which "the partitioning process that was involved in some understood opposition (between groups or linguistic varieties, for example) recurs at other levels, creating either subcategories on each side of a contrast or super-categories that include both sides but oppose them to something else" (Irvine and Gal 2000:38). For example, while an opposition between Swedish and English has been suggested above, fractal recursivity might result in further oppositions, for example between super-categories that sees Swedish and English speakers in opposition to Mandarin speakers, or between sub-categories that sees Mandarin speakers confident speaking in a greater range of registers in opposition to Mandarin speakers confident speaking in a lesser range of registers (see section 6.3). Fractal recursivity points to the replicability, but also the fluidity and mutable natures of ideological framings, whereby inequalities between linguistic varieties or ethnic backgrounds can recur, but also be reworked within any given order.

Finally, erasure is a process in which particular linguistic variations, for example within linguistic practices and repertoires, are simplified, rendering some practices or resources invisible. As we have already seen in the debate surrounding internationalisation in Sweden, there is a dualistic ideological process that represents Swedish as the language of Sweden and English as the language of internationalisation, thus erasing the diversity within these categories. Of course, in this example, the diversity remains, but it is largely ignored and rendered invisible in the discourse.

With this theoretical toolbox and the above stated goals in mind (see esp. section 1), I seek to address the following research questions:

1) How are orders of visibility constructed in the discourse of my participants and what are the shared frames of reference therein? 
2) How do my participants experience and respond to the language policies, ideologies and practices associated with 'internationalisation'?

\section{Material and methods}

A natural sciences department was chosen since the objects under investigation there have no foundational relationship to the Swedish context and can be as usefully investigated and explained in any language (cf. Salö 2017: 21ff for a discussion of what matters to different disciplines). It is in the natural sciences, de Swaan (2004: 141) suggests, that "most of what can be said in English can also be phrased in mathematics and in formal schemes". The social and linguistic demands that the scientific department studied here places on its staff and students, then, can more reliably be said to be the outcome of a historical "struggle over the definition of the legitimate principles of division of the field" (Bourdieu 1985: 208) rather than of any absolute research or teaching related necessity to be able to hold certain and specialised linguistic resources. This choice was especially important in this study, since I seek to direct attention to the ways in which the language perceptions and practices in the department are suffused with the political and social processes beyond the department, which are associated with the internationalisation of universities. Thus the perceptions and their objects at this department, i.e. interactions and local practices and processes, were considered to be more predisposed to being shaped by other social practices and processes across space and time (Heller 2006, 2011; Rampton 2006).

Processes of internationalisation have been particularly prevalent in the department in focus, and this allowed me to access international departmental staff and students that entered both before and after the forces and debates surrounding internationalisation in Swedish HEIs erupted (see section 1). Although I interviewed nine participants in total (in English), this study draws on data gathered from just three participants (see table 1). The three participants 
(all given pseudonyms) were put into focus since at various points of these three interviews there were crossovers and conflicts across their responses that I believe allowed for a more integrated and in-depth analysis that relates to the themes most relevant to the field of Language Policy and Planning. Before carrying out the interviews, I also attended and made field notes in a special - cake was on offer - departmental meeting where all three participants were present. As table 1 shows, the participants in focus here held different volumes of academic power. Selecting participants at different positions in the institutional hierarchy provided me with the opportunity to explore and take into consideration issues of departmental power relations present in the participant responses.

The participants were recruited through "snowball sampling” (Lincoln \& Guba 1985; Dörnyei \& Csizér 2011). In other words, having interviewed my first participant (Wanda) who I contacted via email, she gave an overview of the various international staff and students in her department who she then introduced me to, also via email.

\section{[Insert Table 1: Participants here]}

\begin{tabular}{|c|c|c|c|}
\hline & Wanda & Brian & Susan \\
\hline Origin & Southeast Asia & North America & North America \\
\hline Reported L1 & Mandarin / Malay & English & English \\
\hline Other languages & $\begin{array}{l}\text { Malay } \\
\text { English } \\
\text { Basic Swedish }\end{array}$ & Basic Swedish & Swedish \\
\hline Academic Position & PhD Student & Associate Professor & Professor \\
\hline $\begin{array}{l}\text { Future academic } \\
\text { plans }\end{array}$ & $\begin{array}{l}\text { To stay in Sweden or } \\
\text { Europe and continue } \\
\text { in academia. }\end{array}$ & $\begin{array}{l}\text { Try to advance } \\
\text { career in Sweden }\end{array}$ & $\begin{array}{l}\text { To remain at current } \\
\text { institution until } \\
\text { retirement. }\end{array}$ \\
\hline
\end{tabular}

Table 1: Participants. N.B. All have been assigned pseudonyms by the author. 
All participants signed a consent form that outlines the project and states my intention to audio record the interviews. The consent form also states that I will do all in my power to reduce the risk of participant recognition in any published work or presentations. It is also stated that I will safely secure any documents and files that contain personal information that might be traced back to them. I also verbally discussed this with my participants to check for full understanding and consent. After attending the staff meeting, to which I was invited by the head of department (who had also been informed about my research prior to it starting), I obtained verbal consent from Susan to give an account of what happened there.

The interview questions were piloted on my colleagues before the interviewing process began. This was done in order to reduce the number of any leading questions and to avoid the use of sensitive and value-laden concepts such as "outsider", "disadvantage", “problem”, etc. (Kuteeva and McGrath 2014).

Sat in the participants own department building, I started the interviews according to the grand tour and mini tour elicitation techniques as devised by D'Andrade (1976) and Spradley (1979) and described in Johnson \& Weller (2002). Beginning the grand tour, the participants and I discussed their educational and professional background and their personal journey that had led them to their current academic position. We spoke generally about their current work and their day to day activities in the department, the different communicative events that occur there and the spaces in which they occur. The information gathered in this grand tour then led on to some more specific linguistic and socio-cultural questions - the participants were asked to relate the general information already covered to their own perspectives on the communicative and social practices they enter into as a member of that department. I also asked for their interpretations of certain events - why they unfolded like they did and whether this is normal or exceptional in some sense. To ensure that we discussed in-depth all the working and social practices and processes I felt were relevant to this study, I 
included a free recall task (Johnson \& Weller 2002: 501) in which the participants were asked to go through some specific working and social practices, processes and situations. The interviews lasted for around 1 hour each.

Interviews were transcribed using a broad orthographic transcription. Minimal responses, e.g. 'um', 'uh huh', 'right' were considered for the initial analysis, but excluded from the extracts below as a result of the level of detail addressed here. Interview summaries were written that include references to aspects considered salient in relation to the research questions. The summaries were discussed with peers and senior colleagues with a view to justifying my analytical mapping and choice of interview excerpts (Miles \& Huberman 1994: 61). The analysis of these excerpts was also critiqued and commented upon during a number of academic presentations and data sessions, allowing for a more considered and developed analysis.

\section{Results and Discussion}

The analysis suggests that a certain order of visibility is constructed in the interview accounts, that is, certain linguistic and social qualities seem to point to (index) the ideal academic, in contrast to which all other linguistic and social qualities are rendered less visible. The results will be discussed according to this order, starting with the most visible and developing the analysis in such a way that proceeds to reveal gradually what remains almost invisible.

\subsection{Susan: iconization and categorisations of national belonging}

All three participants regarded themselves as having international status at their place of work. However, when it came to describing the different languages spoken in the department, both Wanda and Brian raised a question about whether their senior colleague, 
Susan, on account of her speaking Swedish, was a national or international colleague. Wanda commented that Susan "was born in the US", but that she "is a Swede now. She speaks fluent English and Swedish". Brian reproduced the same idea, suggesting that "[Susan] is a Swede now”. As Irvine and Gal (1995: 973) comment, it has become a commonplace in sociolinguistics, that linguistic phenomena, including whole languages, can index social groups. Both Wanda and Brian's comments make a link between Susan's ability to speak fluent Swedish (and perhaps also her long-term residency in Sweden) and the national category of Swedish-ness, suggesting a certain iconicity that comes with the ability to speak fluent Swedish. The dichotomy of Swedish and English as two fixed languages, representing the national and international respectively (see above), is reproduced here in the discourse of two international employees, in a process of iconization that serves to construct Susan as someone who is not really an international employee anymore. She has found her way into club Sweden - apparently, the place to be.

This process of iconization emerged, perhaps more forcefully, in a departmental event in which Susan was introduced before she was asked to speak. The head of the department, another international employee, fluent in both Swedish and English, discussed her career trajectory in his introduction, finishing his account by jokingly announcing that Susan had done so well in her career that she can now be considered an "honorary Swede". This comment raised a laugh and Susan smiled before taking the floor. When I raised this in the interview with Susan, however, she "didn't quite agree" at the way she was and continues to be frequently positioned as Swedish. In response she told me, “I don't feel 100\% Swedish, but I don't feel 100\% American either. [...] I can metamorphose into something different to fit in". Although not in agreement with her categorisation, Susan confidently dismissed the comments suggesting that it is of no consequence to her, since she can, essentially, "metamorphose" and be who she wants to be. So, although her international status was 
subjected to the ideological process of erasure, it appears that this is of no great loss to her, since she feels that she is able to transcend the national / international dichotomy. Indeed, embarking on a potentially face-threatening speech act, by publicly erasing Susan's international background and bestowing the honour of Swedish-ness on her, albeit jokingly, we can surmise that her colleague knew exactly what he was doing. That what it is that gets her into "club Sweden" is something that is indeed coveted by others. His audience's laugh worked to confirm as much.

Indeed, Wanda and Brian's construction of Susan as a Swede (see extracts above) were not made in an attempt to undermine her, as was revealed in the warm and complimentary evaluations of Susan as a supervisor and researcher preceding and following those comments. The process of iconization emergent in the discourse discussed here reveals the desirability of Susan's own linguistic repertoire and perhaps even the pleasure one might take in being able to lose one's international status. Although, introduced in the staff meeting in English, the language of the international university, it is clearly a point of great importance that Swedish is also a part of Susan's linguistic repertoire. Indeed, as we shall see from Brian's account of the power-laden working practices in the department, a repertoire consisting of only English is not as optimal as one might be led to believe.

\subsection{Brian: a more "international” employee}

Susan came into the Swedish academic field at a time before the discourse of internationalisation had developed, i.e. pre-1990s. She entered Swedish HE at a time when university courses were expected to be taught in Swedish and when the possibility of getting by in an academic career without a knowledge of Swedish was not there. Then, after Susan had acquired the linguistic resources to teach and fulfil certain administrative duties in Swedish, and when the discourse and forces of internationalisation erupted in the 1990s, 
certain structural demands on staff and students changed. Yet by this time, Susan, through structural necessity - responding to the forces and relations within the scientific field - had actively embodied the academic "habitus" necessary to progress in Swedish HE and enter into a position of power. Defined by Bourdieu (1977:82) as "the past which survives in the present", the habitus of those in positions of power allows us to consider the extent to which the structural requirements placed on those entering a given field has changed. With internationalisation, if one does not have Swedish and thus the identity of an "honorary Swede", can one gain positions of power in Swedish HE? Brian's experiences and thwarted ambitions would suggest not.

Asked about his working practices and the extent to which he feels he is progressing in his academic career, Brian told me:

There are certain committees within my department where I have not been able to participate. I have volunteered to participate in them, and have been told, just flat out, that I can't. Because I don't understand Swedish, and you have to understand Swedish for these meetings, which has seemed, I don't think that this is entirely fair. You know, if we are trying to promote ourselves as an international department, with international employees, I don't think you can limit these committees which are part of the administration of the department, to just Swedish speaking employees.

Brian's concern over the obstacles he faces in progressing in the Swedish field and his concern with a certain unfairness, due to his department's administrative language practices being more fixed suggest that what is to be a successful member of staff in an international 
department is somewhat obscured. As described above (see section 2), the construction of contemporary academia as "international" largely relates to the 'Englishisation' of the academic market, whereby regions, nation states and local institutions, with a view to becoming more globally competitive, in certain practices allow for and encourage the use of English. Indeed, going against his university policy, Brian was even given teaching hours to undergraduates that he taught, (albeit with a Swedish speaking assistant), in English. Thus, his involvement in the department, together with his research output, even as an English-only speaker, was in certain senses highly valued. But, as his comments suggest, on entering Swedish academia without a certain linguistic repertoire, only certain doors were open for Brian.

In certain respects, English can be said to be lower down in the order of visibility in Swedish academia than one may come to assume from the discourses constructing the internationalisation as "Englishisation" as an existential threat to Swedish. Indeed, continuing his description of his day-to-day life in the department and the more administrative aspects of his communication, Brian suggested that the lack of English was sometimes a more threatening issue.

There are other instances where we've received, erm, administrative emails, or emails from the building manager related to safety, gas, maintenance that have been entirely in Swedish [...] When your inbox is already plugged, and you don't instantly understand something and kind of compartmentalise it into important or not important, and it's just in Swedish, then sometimes, if I'm really busy, it will just be put on the 'deal with later pile' and then it just doesn't get dealt with. 
Brian's concern for his well-being and future career and his critique of the power structures and linguistic practices suggests the need for a more "international" department in which English speakers are shown more care and given further access to positions of power. This draws attention to the fixed-ness of the language hierarchy in Swedish HE, whereby a logical response to such perceived inequalities, unfairness and safety issues would be to engage in a struggle by which English gains more legitimacy in Swedish HE. After all, flirting with the discourse of internationalisation, what Brian experiences is presumably unfair (see extract 1 ) because English is that which allows universities to compete on the global market. In this struggle for power, what then of those that speak other languages? What resources do they bring to department that might perhaps afford them greater volumes of symbolic capital? How are those that speak languages other than Swedish and English constructed as part of the orders of visibility?

6.3 Wanda, fractal recursivity and invisible international working practices

Wanda is a PhD student from southeast Asia, but she told me the only east-Asian in the department who is most comfortable speaking English and Malay for academic purposes. There were 5 Mandarin speakers in the department, including Wanda, who often ate lunch together. This situation suited Wanda since she reported being comfortable in only more informal registers of Mandarin Chinese, as her secondary and undergraduate education had been in Malay and English and because she reported using Mandarin only to speak to friends and family, not to speak about her academic work. As such, she expressed her gratitude for being accepted "as one of the members of the group because they are all the Chinese group and they always include me and then invite me for any kind of gatherings and such". Positioning herself as an outsider in this group, Wanda's comments reveal a complexity to the "Chinese group" that is perhaps not visible to others. 
In a manner similar to Susan, the ideological process of iconization served to transform her ability to speak Mandarin Chinese into a Chinese identity. This can be seen in a comment Brian made when asked which languages were spoken in the department:

Chinese is there. This is a bit of an issue, because I feel like, erm, the Chinese are obviously the most comfortable speaking Chinese. They tend to eat lunch together and socialise together and I feel like they're almost, they become a little bit segregated from... This is perhaps something we need to work on, in the department as a whole. As integrating them more and... But yeah, so when they are having lunch together, it's sort of exclusively in Chinese. Even if there's a mix of people from our department having lunch, the Chinese come downstairs and just have lunch together.

While serving to erase Wanda's own trajectory, linguistic and social resources, the construction of a homogeneous Chinese "them" here as separated from the "mix of people", indexes a new opposition in the department. This ideological and spatially realised opposition is between the Chinese and non-Chinese, not between the national and international - the Swedish and the English. The construction of this new opposition can be understood through the notion of fractal recursivity (see section 4 above), whereby a super-category, 'the Chinese', is positioned in opposition to everyone who falls outside of this category. For Wanda, of course, speaking in terms of named and fixed languages, there is further fractalization in the way she described herself as somewhat of an outsider to the Chinese grouping on account of her more limited Mandarin repertoire, revealing subcategorizations in an opposition between Wanda and those more confident to use Chinese in a wider range of 
registers. Despite her rich linguistic repertoire, then, a significant proportion of the resources therein are rendered invisible in relation to the department's orders of visibility.

The iconization of all Chinese Mandarin speakers being Chinese is seen to bring certain complications for Wanda. When discussing the communicative and working practices of the PhD and post-doc students in the department, Susan suggested that things are most difficult with the Chinese students. As she described, "we have so many Chinese students now and I am trying desperately to understand how they think, $[\ldots]$ how to get them to think creatively". When giving more detail about this and in trying to rationalise the situation, she commented, "I have a PhD student who comes from [country anonymised by author / suggesting Wanda], and the same thing with all the people from China. It has something to do with where they are coming from, that it is so big, and has so many people and is very authoritarian". From the mere fact that Wanda speaks Mandarin Chinese, she is depicted as sharing the essentialising polite, obedient, but passive and uncreative Chinese student stereotype (Wei \& Wu 2009) common in educational discourse (at least). Coming from a professor with significant academic power, such essentialisations stemming out of processes of iconicity may prove problematic for $\mathrm{PhD}$ candidates such as Wanda who may seek further employment in similar north European universities. What might it take to change such perceptions and are international students involved in practices that might both contradict and come to disrupt them?

With a view to identifying the affordances of a multilingual albeit partially invisible repertoire in academic working practices, I asked Wanda a series of questions and went through a free recall task (see section 5 above) on the topic of her working practices and which languages she uses at the various stages of writing a research paper. The first time I raised the issue, she told me that, "I always force myself to think in English because I didn't learn scientific writing in Mandarin or the Malaysian language [sic]" and that, 
"for me, everything related to Science is in English". These claims correspond to the dominance of English in academic, especially scientific publishing, as well as to the “international as English” ideology outlined in section 2, whereby international academics only operate in English. However, as I asked more detailed questions as part of the mini-tour (see section 4 above) towards the end of the interview, certain contradictions and more complex and creative practices came to light.

Describing how she wrote her first paper as part of her compilation $\mathrm{PhD}$ thesis, Wanda told me about the writing process and how she went about writing the paper together with another researcher. She collaborated with a PhD student based in Holland, where she travelled to do the 3-month long experiment / data collection. This other student was from China and spoke Mandarin as his first language. Wanda told me that, "[w]e communicate mostly in Mandarin, but when we have to write, we write in English. Like, we WhatsApp in English and then we will write a paper together in English. But other than that, we use Mandarin [...]". So, after extensive questioning it turns out that although the finished product demanded English, the resources in her multilingual repertoire allowed her to complete her first paper, which was subsequently published. Crucially, such working practices demand a certain creativity. In order to circumnavigate the linguistic demands placed on her in such a situation, since Wanda had already described her linguistic repertoire as having minimal resources for engaging in academic registers in languages other than English and Malay, Wanda was required to go 'above and beyond herself'.

Such multilingual practices as part of the writing process within academic publishing are not undocumented. As Salö (2015: 518) writes in a study on the entextualisation of working practices that consist of more than one language in Swedish academia, citing Canagarajah (2013: 8), "while the textual product aimed for a global communicative market may be monolingual, the discursive practices that feed into its production may contain 
multiple linguistic resources" (see also Hynninen \& Kuteeva, this volume). Pursuing an understanding of the sense of unease in Wanda's accounts of such practices in the interview, I asked her why she thought they had worked in Mandarin. She responded by stressing the fact that "sometimes I speak in Mandarin and sometimes I speak in English" and that "[I] found it [talking about the experience] very weird. (Laughs)".

The contradiction between her initial and later comments on the issue, combined with her surprise and uneasiness in admitting to the fact that she used Mandarin in the research process suggest a soft violence. As a result of the ideological processes by which one's practices are only made visible if done through certain languages (Swedish or English), Wanda was not accustomed to discussing or making visible the value and use of her resources. Asking why Wanda found it strange to talk about her use of Mandarin as part of the paper-writing process, she responded that, "only when we are talking face to face, without the presence of other people, do we use Mandarin”. Multilingual practices that are accruing value for modern internationalised universities (i.e. by means of (trans-local) multilingual writing processes) are not seen here to be eradicated, but they are nonetheless subject to the process of erasure.

\section{Concluding Remarks}

My participants' everyday experiences of contemporary university life in a sciences department in Sweden and their responses to those experiences reveal a shared frame of reference, in which linguistic practices and repertoires, as well as the identities indexed by such linguistic phenomena, exist according to a certain order of visibility. Similarities were found in the perceptions of those with different linguistic resources and volumes of academic power with the language policies, ideologies and practices related to internationalisation in Sweden. In this way, the focus on two named languages, Swedish and English, is reproduced 
in a hegemonic fashion (Gramsci 1971), whereby ideological structures appear even without the presence of a locatable powerful authority. The ideological processes of iconicity, fractal recursivity and erasure have been shown to be effective in revealing the ways in which certain ideological structures are reproduced in a way that constructs a more local, but potentially reworkable order of visibility. The re-workability of such an order is perhaps that which should invite researchers and policy makers to take more seriously the perceptions and practices of those on the ground in contemporary HEIs.

While this study is limited by the number of participants and the minimal amount of time spent dwelling in the departmental spaces, its findings suggest fruitful avenues for future research. Further insights gained from revealing how contemporary university life is actually experienced, perhaps by employing a wider range of ethnographic methods, will provide an instructive and illuminating picture of the clear mismatch between the complexity of what is going on "on-the-ground" and the reductive and restrictive concern for bounded and fixed language systems. Such research will also serve to make certain invisible value-laden linguistic practices and processes visible, thereby disrupting the monoglossic language ideologies that are frequently being reproduced (or at least left unchallenged) by a great many policy makers and scholars concerned with the practices and processes of internationalisation. 


\section{Acknowledgments}

I would like to thank my doctoral supervisors, Caroline Kerfoot and Linus Salö, as well as Niina Hynninen, Maria Kuteeva and an anonymous reviewer for reading drafts and offering valuable comments and suggestions at various stages of the writing process. I would also like to thank Fredrik Bissinger, Anette Jansson, Adam Jaworski, Kathrin Kaufhold, Ekaterina Malik, Henrike Messer, Natalia Volvach, Lasse Vuorsola and Beatrice Zuaro for their generous feedback and comments given in response to presentations of this work. 


\section{$\underline{\text { References }}$}

Airey, J., Lauridsen, K., Räsänen, A. Salö, L. \& Schwach, V. (2017) The expansion of English-medium instruction in the Nordic countries. Can top-down university language policies encourage bottom-up disciplinary literacy goals? Higher Education. Vol. 73(4). Pp. 561-576.

Berg, E.C; Hult, F.M. \& King, K.A. (2001) Shaping the climate for language shift? English in Sweden's Elite Domains. World Englishes. Vol. 20 (3). Pp. 305-319.

Blommaert, J. (2010) The Sociolinguistics of Globalization. Cambridge: Cambridge University Press.

Bourdieu, P. (1977) Outline of a Theory of Practice. Cambridge: Cambridge University Press.

Bourdieu, P. (1985) Social Space and the Genesis of Groups. Social Science Information. Vol. 24 (2). Pp. 195-220.

Canagarajah, S. (2013) Translingual Practice: Global Englishes and Cosmopolitan Relations. London: Routledge.

Committee for the Swedish Language (2002) Mål i mun: förslag till handlingsprogram för svenska språket: betänkande. Stockholm: Fritzes offentliga publikationer

D'Andrade, R. (1976) 'Propositional analysis of US American beliefs about illness'. In Keith H. Basso \& Henry A. Selby (eds.), Meaning in anthropology. Albuquerque, NM: University of New Mexico Press. Pp. 155-180.

de Swaan, A. 2004. English in the Social Sciences. ALLEA Biennial Yearbook 2004. Pp. $135-146$.

Dörnyei, Z. \& Csizér K. (2011) 'How to design and analyze surveys in second language acquisition research'. In Alison Mackey \& Susan Gass (eds.), Research methods in second language acquisition: A practical guide. Chichester: Wiley-Blackwell. Pp. 74-94.

Gal, S. \& Irvine, J. T. (1995) The boundaries of Languages and Disciplines: How Ideologies Construct Difference. In Social Research. Vol. 62.(4). Pp. 967-1001.

Gramling, D. (2016) The Invention of Monolingualism. London: Bloomsbury.

Gramsci, A. (1981) Selections from the Prison Notebooks. Trans. and ed. by Q. Hoare and G. Nowell Smith. New York: International Publishers.

Gunnarsson, B.-L. (2001) Swedish, English, French or German - The Language Situation at Swedish Universities. The Dominance of English as a Language of Science. Effects on Other Languages and Language Communities, edited by U. Ammon. Berlin, New York: Mouton de Gruyter. Pp. 229-316. 
Gunnarsson, B.-L. \& Öhman, K. (1997) Det internationaliserade universitetet. En studie av bruket av engelska och andra främmande språk vid Uppsala universitet [The Internationalized University. A Study of the Use of English and Other Foreign Languages at Uppsala University]. Text-och fackspråksforskning 16. Uppsala: Institutionen för nordiska språk, Uppsala universitet.

Heller, M. (2006) Linguistic Minorities and Modernity: A Sociolinguistic Ethnography (2nd edition). London: Continuum.

Heller, M. (2007) 'Bilingualism as ideology and practice', in Monica Heller [ed.], Bilingualism: a social approach. Basingstoke: Palgrave. Pp. 1-24.

Heller, M. (2011) Paths to Post-Nationalism. A Critical Ethnography of Language and Identity. Oxford: Oxford University Press.

Hult, F. M. (2012) English as a Transcultural Language in Swedish Policy and Practice. TESOL Quarterly. Vol. 46 (2). Pp. 230-257.

Hult, F. M., \& Källkvist, M. (2016). Global flows in local language planning: Articulating parallel language use in Swedish university policies. Current Issues in Language Planning. Vol. 17 (1). Pp. $56-71$.

Irvine, J. T. \& Gal, S. (2000) Language Ideology and linguistic differentiation. In P.V. Kroskrity (ed.), Regimes of language: Ideologies, polities and identities. Santa Fe: School of American Research Press. Pp. 35-84.

Johnson, J. \& Weller, S. (2002) 'Elicitation techniques for interviewing'. In Jaber Gubrium \& James Holstein (eds.). Handbook of interview research. Thousand Oaks, CA: Sage. Pp. 185-204.

Källkvist, M. \& Hult, F. M. (2016) 'Discursive mechanisms and human agency in language policy formation: Negotiating bilingualism and parallel language use at a Swedish university'. International Journal of Bilingual Education and Bilingualism. 19 (1). Pp. 1-17.

Karlsson, S. \& Karlsson, T. S. (2019) 'Language policy as 'frozen' ideology: exploring the administrative function in Swedish higher education'. In Current Issues in Language Planning. Pp. 1-22.

Kauppi, N. \& Erkkilä, T. (2011) The Struggle Over Global Higher Education: Actors, Institutions, and Practices. In International Political Sociology. Vol. 5. Pp. 314-326.

Kerfoot, C. \& Hyltenstam, K. (eds.) (2017) Entangled Discourses. South-North Orders of Visibility. New York: Routledge.

Kerfoot, C. \& Tatah, G. (2017) 'Constructing Invisibility: The Discursive Erasure of a Black Immigrant Learner in South Africa'. In Caroline Kerfoot \& Kenneth Hyltenstam (eds.), Entangled Discourses. South-North Orders of Visibility. New York: Routledge. Pp. 38-58.

Kirkpatrick, A. (2014) The language (s) of HE: EMI and/or ELF and/or Multilingualism?. The Asian Journal of Applied Linguistics. Vol. 1 (1). Pp. 4-15. 
Kuteeva, M. \& Airey, J. (2014) Disciplinary differences in the use of English in higher education: reflections on recent language policy documents. In Higher Education. Vol. 67 (5). Pp. 533-549.

Kuteeva, M. \& McGrath, L. (2014) Taming Tyrannosaurus rex: English use in the research and publication practices of humanities scholars in Sweden. Multilingua. Vol. 33 (3-4). Pp. 365-387.

Lillis, T. \& Curry, M.J. (2010). Academic Writing in a Global Context: The policies and practices of publishing in English. Oxon: Routledge.

Lincoln, Y. \& Guba, E.G. (1985) Naturalistic Inquiry. London: Sage.

Melander, B. \& Thelander, M. (2006). Så tar man livet av ett språk. Språkvård. Vol. 2. Pp. $39-42$.

Milani, T. \& Johnson, S. (2008). Language politics and legitimation crisis in Sweden: A Habermasian approach. Language Problems and Language Planning. Vol. 32 (1). Pp. 1-22.

Miles, M. \& Huberman, M. (1994) Qualitative data analysis: An expanded sourcebook. Thousand Oaks, CA: Sage.

Nordic Council of Ministers (2007) Deklaration om nordisk språkpolitik 2006 [Declaration on Nordic Language Policy 2006]. Kopenhamn: Nordiska Ministerrådet.

http://norden.org/da/publikationer/publikationer/2007-746/at_download/publicationfile.

Otsuji, E. \& Pennycook, A. (2011) 'Social inclusion and metrolingual practices'. International Journal of Bilingual Education and Bilingualism. Vol. 14: 4. Pp. 413-426.

Paasi, A. (2005) Globalisation, academic capitalism and the uneven geographies of international journal publishing spaces. In Environment and Planning. Vol. 37. Pp. 769-789.

Prop. 2004/05:162. (2004) Ny värld - ny högskola. Stockholm: Swedish Government.

Prop. 2005/06:2. (2005) Bästa språket - en samlad svensk språkpolitik. Stockholm: Swedish Government.

Prop. 2008/09:153. (2008) Språk för alla - förslag till språklag. Stockholm: Swedish Government.

Rampton, Ben. (2006) Language in Late Modernity. Cambridge: Cambridge University Press.

Salö, L. (2010) Engelska eller svenska? En kart- läggning av språksituationen inom högre utbild- ning och forskning [English or Swedish? Linguistic Landscape in Swedish Higher Education and Research]. Stockholm: Språkrådet. 
Salö, L. (2015) 'The Linguistic sense of placement: Habitus and the entextualisation of translingual practices in Swedish Academia'. Journal of Sociolinguistics. Vol 19 (4). Pp. 511-534.

Salö, L. (2016) Languages and linguistic exchanges in Swedish academia. Stockholm: Stockholms universitet.

Salö, L. (2017) The Sociolinguistics of Academic Publishing: Language and the Practices of Homo Academicus. Cham: Palgrave Macmillan.

SFS (2009:724) National minorities and minority languages act. Stockholm: Ministry of Culture.

Song, Y. (2015) The provision of English language training in IT outsourcing companies in China. (Unpublished PhD Thesis). University of South Australia.

Spradley, J. (1979) The ethnographic interview. New York: Holt, Reinhart \& Winston.

Swedish Higher Education Authority (2008) En högskola i världen - internationalisering för kvalitet. Stockholm: Högskoleverket.

Teleman, U. (1993) Det svenska riksspråkets utsikter I ett intergrerat Europa [The Outlook for Swedish in an Integrated Europe]. Speak $i$ Världen: Broar och Barriärer. Pp. 127-41.

Wächter, B. \& Maiworm, F. (2008) English-taught programmes in European Higher Education: The picture in 2007. Bonn: Lemmens.

Wächter, B. \& Maiworm, F. (2014) English-taught programmes in European Higher Education: The state of play in 2014. Bonn: Lemmens.

Wee, L. (2016) 'Are there zombies in language policy? Theoretical interventions and the continued vitality of (apparently) defunct concepts'. In Nikolas Coupland (ed.), Sociolinguistics: Theoretical Debates. Cambridge: Cambridge University Press. Pp. 331348.

Wee, L. (2017) Institutional Constraints on Flexible versus Fixed Multilingualism. The Case of Parallel Language Ideology in Sweden. In Caroline Kerfoot \& Kenneth Hyltenstam (eds.), Entangled Discourses. South-North Orders of Visibility. New York: Routledge. Pp. 137-153.

Wei, L. \& Wu, C.-J. (2009). Polite Chinese children revisited: creativity and the use of codeswitching in the Chinese complementary school classroom. International Journal of Bilingual Education and Bilingualism. Vol. 12 (2). Pp. 193-211 